\title{
Yield and nutrient uptake by wheat as influenced by integrated use of manures and fertilizers
}

\author{
M. R. Islam*, M. S. Shaikh, A. B. Siddique ${ }^{1}$ and M. H. Sumon \\ Department of Soil Science, Bangladesh Agricultural University, Mymensingh-2202, Bangladesh and ${ }^{1}$ Department of \\ Coastal Agriculture, Noakhali Science and Technology University, Sonapur, Noakhali-3814, Bangladesh, *E-mail: \\ mrislam69@yahoo.com
}

\begin{abstract}
An experiment was conducted at the Soil Science Field Laboratory of Bangladesh Agricultural University, Mymensingh during November 2011 to March 2012 to evaluate the effect of integrated use of manures and fertilizers on the growth, yield and nutrient uptake by wheat. There were six treatments such as $\mathrm{T}_{0}$ (Control), $\mathrm{T}_{1}$ [STB-CF

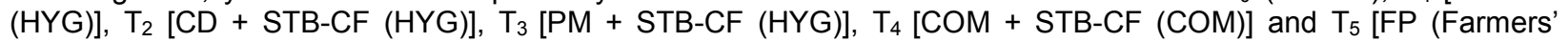
practice)]. The experiment was laid out in a Randomized Complete Block Design with four replications. The integrated use of manures and fertilizers significantly influenced the yield attributes as well as grain and straw yields of wheat. The treatment $\mathrm{T}_{1}$ [STB-CF (HYG)] produced the tallest plant of $90.17 \mathrm{~cm}$ which was identical with $\mathrm{T}_{3}$ [PM + STB-CF (HYG)] and the lowest value was found in control. The 1000-grain weight followed the similar pattern but the tillers hill ${ }^{-1}$, spike length and spikelets spike ${ }^{-1}$ did not follow any definite trend. The treatment $\mathrm{T}_{3}[\mathrm{PM}+\mathrm{STB}-\mathrm{CF}$ (HYG)] produced the highest grain yield of $4362 \mathrm{~kg} \mathrm{ha}^{-1}\left(90.4 \%\right.$ increase over control) and straw yield of $5492 \mathrm{~kg} \mathrm{ha}^{-1}$ $\left(84.79 \%\right.$ increase over control). The lowest grain yield $\left(2291 \mathrm{~kg} \mathrm{ha}^{-1}\right)$ and straw yield $\left(2972 \mathrm{~kg} \mathrm{ha}^{-1}\right)$ were found in $\mathrm{T}_{0}$ (Control). The NPKS uptake by wheat was markedly influenced by combined use of manures and fertilizers and the treatment $\mathrm{T}_{3}$ demonstrated superior performance to other treatments. So the treatment $\mathrm{T}_{3}$ comprising poultry manure in combination with chemical fertilizers on IPNS basis was found to be the best combination of manures and fertilizers for obtaining the maximum yield and quality of wheat at BAU farm.
\end{abstract}

Keywords: Manures and fertilizers, Wheat, Yield, Nutrient uptake

\section{Introduction}

Wheat (Triticum aestivum L.) is the world's leading cereal crop both in area and production and about two-third people of our planet live on it. In Bangladesh, it ranks next to rice and its popularity is increasing consistently. The average yield of wheat in this country is quite low as compared to that of wheat growing countries of the world like China and Japan.

The organic matter content as well as the fertility status of Bangladesh soil is decreasing day by day (BARC, 2012). This depletion has arisen mainly due to continuous mining of soil nutrient over decades without adequate replenishment. Now, it is well agreed that depleted soil fertility is a major constraint for higher crop production in Bangladesh and indeed, the yield of several crops are declining in some soils. Maintenance of soil fertility is a prerequisite for long term sustainable agriculture and organic manure can play a vital role in sustaining soil fertility and crop production.

Since fertile soil is the fundamental resource for higher production, its maintenance is a prerequisite for long term sustainable crop production of crops cannot be maintained by using chemical fertilizers alone and similarly, it is not possible to obtain higher crop yield by using only organic manure (Bair, 2000). Nambiar (2000) viewed that integrated use of manure and fertilizers would be quite promising not only in providing greater stability in production, but also in maintaining higher soil fertility status. Akhtar et al. (2011) reported that fertilizer application along with compost increased the yield, N and $\mathrm{P}$ uptake by wheat compared to the fertilizer alone. Toor et al. (2009) conducted an experiment on the effect of application of poultry manure, farm yard manure and urea on available nutrient status of soil in wheat and observed that poultry manure was more effective than farm yard manure for available $N$ and $P$. The long term research conducted by Bangladesh Rice Research Institute and BAU, Mymensingh reveals that the addition of dung manure along with inorganic fertilizers improves rice productivity as well as prevents the soil resource from degradation. Thus we need to use manure and fertilizer in an integrated way in order to obtain economically profitable crop yields without unacceptable loss to the soil resource. 
The organic matter in various forms and at various stages of decomposition has been used in soil in tons $\mathrm{ha}^{-1}$ for improvement of crop productivity. The use of inorganic chemical fertilizers is essential for crop nutrition in order to maximize productivity. The crop yields especially of wheat are stagnant for the last couple of years (BBS, 2010). The use of organic manures along with chemical fertilizers may be effective for further increase in crop yield. The present investigation was, therefore, undertaken to study the effect of manures and fertilizers in IPNS (Integrated Plant Nutrient Management System) system on the growth, yield and nutrient uptake by wheat.

\section{Materials and Methods}

The experiment was carried out in the Soil Science Field Laboratory of Bangladesh Agricultural University, Mymensingh during during November 2011 to March 2012. The soil belongs to Sonatala series under the AEZ of the Old Brahmaputra Floodplain. The experimental soil was silt loam in texture having $\mathrm{pH} 6.94$, organic matter $1.62 \%$, total nitrogen $0.067 \%$, available phosphorus $10.45 \mathrm{mg} / \mathrm{kg}$, exchangeable K $0.08 \mathrm{me} / 100 \mathrm{~g}$ soil, available sulphur $12.00 \mathrm{mg} / \mathrm{kg}$ and cataion exchange capacity 15.0 me/100 g soil. Kanchan, a high yielding variety of wheat was used in this experiment as test crop. The experiment was laid out in a randomized complete block design (RCBD) with four replications. The experiment comprised of 6 treatments: $T_{0}$ (Control), $T_{1}$ [STB-CF (HYG)], $T_{2}$ [CD + STB-CF (HYG)], $T_{3}$ [PM + STB-CF (HYG)], $T_{4}$ [COM + STB-CF (HYG)], $T_{5}$ [FP (Farmers practice)]. Here, STB = Soil Test Basis, $\mathrm{CF}=$ Chemical fertilizer, $\mathrm{CD}=$ Cowdung, $\mathrm{PM}=$ Poultry manure, $\mathrm{COM}=$ Compost, $\mathrm{FP}=$ Farmers' practice, $H Y G=$ High yield goal.

Well decomposed cowdung, compost, and poultry manure were applied to the plots as per the treatments by mixing with the soil well before 7 days of sowing. The nutrient contents of the manures are depicted in Table 1. The amount of N, P, K, S and B required for each plot was calculated considering the fertilizer urea, TSP, MoP, Gypsum and boric acid, respectively. One third of urea, and the full amount of TSP, MoP, gypsum and boric acid were applied one day before transplanting. The rest of urea was applied in two equal splits one at maximum tillering stage (30 days after sowing) and the other at panicle initiation stage (90 days after sowing).

Seeds of wheat were sown on 30 November 2011 @ $150 \mathrm{~kg} \mathrm{ha}^{-1}$ in lines and covered by soil with hand. The line to line distance was $20 \mathrm{~cm}$ and the depth of furrow was about $6 \mathrm{~cm}$. A strip of wheat crop was established as border crops. Intercultural operations such as irrigation and weeding were applied as and when necessary. The crop was harvested at full maturity. Grain yield was recorded on $14 \%$ moisture basis and straw yield on sun dry basis. Five hills were randomly selected from each plot at maturity to record the yield contributing characters. Grain and straw samples were analyzed for NPKS consents following standard methods (Page et al., 1982). The NPKS uptake by grain and straw was calculated from their contents and yield data. All the data were statistically analyzed by F-test and the mean differences were ranked by DMRT at $5 \%$ level (Gomez and Gomez, 1984).

Table 1. Nutrient contents in cowdung, compost and poultry manure

\begin{tabular}{|l|c|c|c|c|}
\hline \multirow{2}{*}{ Manure } & \multicolumn{4}{|c|}{ Nutrient contents } \\
\cline { 2 - 5 } & $\% \mathrm{~N}$ & $\% \mathrm{P}$ & $\% \mathrm{~K}$ & $\% \mathrm{~S}$ \\
\hline Cowdung & 0.57 & 0.47 & 0.69 & 0.23 \\
\hline Compost & 0.89 & 0.30 & 0.45 & 0.46 \\
\hline Poultry manure & 1.18 & 1.13 & 0.81 & 0.35 \\
\hline
\end{tabular}




\section{Results and Discussion}

\section{Yield contributing characters}

Yield contributing characters such as plant height, effective tillers hill ${ }^{-1}$, spike length and spikelets spike ${ }^{-1}$ and 1000-grain weight were influenced significantly due to application of manures and fertilizer in different combinations (Table 2). The tallest plant of $90.17 \mathrm{~cm}$ was observed in $T_{1}$ [STB-CF (HYG)] with the application of chemical fertilizers at recommended dose and it was identical with $\mathrm{T}_{3}$ [PM + STB-CF (HYG)]. The treatments $\mathrm{T}_{2}$ [CD + STB-CF (HYG)], $\mathrm{T}_{4}$ [COM + STB-CF (HYG)] and $\mathrm{T}_{5}$ [FP (Farmers' practice)] produced statistically similar plant height with the value of $77.148 \mathrm{~cm}, 77.44 \mathrm{~cm}$ and $82.69 \mathrm{~cm}$, respectively. The shortest plant of $66.59 \mathrm{~cm}$ was recorded in $T_{0}$. The maximum number of effective tillers hill $^{-1}$ (3.85) was obtained in $T_{1}$ and the minimum number of 2.80 was observed in $T_{0}$. The treatments $T_{0}$, $T_{2}$ and $T_{4}$ showed statistically similar effective tillers hill ${ }^{-1}$. The highest spike length $(11.89 \mathrm{~cm})$ was found in $T_{5}$ (farmers 'practices) which was statistically similar with $T_{1}$. The treatments $T_{2}, T_{3}$ and $T_{4}$ were identical in producing spike length of wheat with the values of $10.91 \mathrm{~cm}, 10.69 \mathrm{~cm}$ and $10.32 \mathrm{~cm}$, respectively. The lowest spike length of $8.585 \mathrm{~cm}$ was obtained in control. The number of spikelets spike ${ }^{-}$ ' due to different treatments ranged from 52.46 to 27.28 and the maximum number was observed in the treatment $T_{1}$. The minimum number of spikelets spike ${ }^{-1}$ (27.28) was found in control. The 1000-grain weight ranged from $53.16 \mathrm{~g}$ to $50.72 \mathrm{~g}$. All the treatments produced significantly higher 1000 -grain weight over control. Many research workers reported that combined application of manures and fertilizers increased the plant height and tillers hill ${ }^{-1}$ (Khan et al., 2007), spike length, ( Singh et al., 2002), and filled grains spike $^{-1}$ ( Satyannarayana et al., 2002).

Table 2. Effect of integrated use of manures and fertilizer on the yield components of wheat

\begin{tabular}{|c|c|c|c|c|c|}
\hline Treatments & $\begin{array}{c}\text { Plant } \\
\text { height } \\
(\mathrm{cm})\end{array}$ & $\begin{array}{c}\text { Tillers hill }^{-1} \\
\text { (No.) }\end{array}$ & $\begin{array}{c}\text { Spike } \\
\text { length }(\mathrm{cm})\end{array}$ & $\begin{array}{c}\text { Spikelets } \\
\text { spike }^{-1} \\
\text { (No.) }\end{array}$ & $\begin{array}{c}\text { 1000- } \\
\text { grains } \\
\text { weight }\end{array}$ \\
\hline $\mathrm{T}_{0}$ (control) & $66.59 d$ & $2.800 \mathrm{c}$ & $8.585 d$ & $27.28 \mathrm{~d}$ & $50.72 b$ \\
\hline $\mathrm{T}_{1}$ [STB-CF(HYG)] & $90.17 a$ & $3.850 a$ & $11.45 a b$ & $52.46 a$ & $52.98 a$ \\
\hline $\mathrm{T}_{2}[\mathrm{CD}+\mathrm{STB}-\mathrm{CF}(\mathrm{HYG})]$ & $77.18 \mathrm{c}$ & $3.150 \mathrm{bc}$ & $10.91 \mathrm{abc}$ & $41.69 \mathrm{bc}$ & $53.14 a$ \\
\hline $\mathrm{T}_{3}[\mathrm{PM}+\mathrm{STB}-\mathrm{CF}(\mathrm{HYG})]$ & $84.73 a b$ & $3.400 \mathrm{~b}$ & $10.69 \mathrm{bc}$ & $45.54 b$ & $52.62 a$ \\
\hline $\mathrm{T}_{4}[\mathrm{COM}+\mathrm{STB}-\mathrm{CF}(\mathrm{HYG})]$ & $77.44 \mathrm{c}$ & $2.825 \mathrm{c}$ & $10.32 c$ & $41.19 c$ & $53.16 a$ \\
\hline $\mathrm{T}_{5}$ [ FP (Farmers' practice)] & $82.69 b c$ & $3.400 \mathrm{~b}$ & $11.89 a$ & $43.67 \mathrm{bc}$ & $52.74 a$ \\
\hline SE $( \pm)$ & 3.70 & 0.163 & 0.470 & 3.38 & 0.285 \\
\hline CV $(\%)$ & 5.46 & 8.41 & 6.09 & 6.16 & 2.04 \\
\hline
\end{tabular}

Figure (s) in a column having common letters does not differ significantly.

STB=Soil Test Basis, CF=Chemical fertilizer, $\mathrm{OM}=$ Organic manure, $\mathrm{CD}=$ Cowdung, $\mathrm{PM}=$ Poultry manure, $\mathrm{COM}=$ Compost, FP = Farmers' practice, $\mathrm{HYG}=$ High yield goal, $\mathrm{CV}=$ Coefficient of variation, $\mathrm{SE}=$ Standard error of means

\section{Grain yield}

The results in Table 3 report that the grain yield of wheat varied significantly due to the integrated use of cowdung, compost, poultry manures and NPKS fertilizers. The highest grain yield (4362 $\left.\mathrm{kg} \mathrm{ha}^{-1}\right)$ was observed in $T_{3}$ [PM+ STB-CF (HYG)] and the lowest value (2291 $\mathrm{kg} \mathrm{ha}^{-1}$ ) was recorded in $\mathrm{T}_{0}$ (control). The grain yield produced by $T_{1}$ [STB-CF (HYG)] was statistically similar with $T_{2}$ [CD + STB-CF (HYG)], $T_{3}$, $\mathrm{T}_{4}[\mathrm{COM}+\mathrm{STB}-\mathrm{CF}(\mathrm{HYG})]$ and $\mathrm{T}_{5}$ [FP (Farmers' practice)] although there was a numerical variation in grain yield among the treatments. Based on grain yield, the treatments may be ranked in order of $T_{3}>T_{1}>$ $T_{2}>T_{4}>T_{5}>T_{0}$. With same recommended fertilizer doses poultry manure treated plots gave higher grain 
yield than cowdung and compost treated plots. This might be due to the presence of uric acids in poultry manure that hastens the release of nutrients from poultry manure than compost and cowdung. The increase in grain yield over control ranged from 74.38 to $90.40 \%$ where the highest increase was obtained in $T_{3}$ and the lowest one was obtained in $T_{5}$. Yakub et. al. (2010) found $6 \%$ increase of grain yield by applying urea- $\mathrm{N}$ and manures. Haque et al. (2001), Asit et al. (2007) and Bodruzzaman et al. (2010) also found increased grain yield with the application of manures and fertilizers in an integrated way.

\section{Straw yield}

The straw yield of wheat also responded significantly due to combined use of manures and fertilizers (Table 3). The maximum straw yield of $5492 \mathrm{~kg} \mathrm{ha}^{-1}$ was found in $T_{3}[P M+S T B-C F(H Y G)]$ and the minimum value of $2972 \mathrm{~kg} \mathrm{ha}^{-1}$ was noted in $T_{0}$ (control). The treatment may be ranked in the order of $T_{3}$ $>\mathrm{T}_{2}>\mathrm{T}_{4}>\mathrm{T}_{1}>\mathrm{T}_{5}>\mathrm{T}_{0}$ in terms of straw yield. Regarding the percent increase of straw yield, the highest increase $(84.79 \%)$ was noted in $\mathrm{T}_{3}$ and the lowest increase $(47.22 \%)$ was observed in $\mathrm{T}_{5}$ FP [farmers' practices]. Akhtar et al. (2011) also observed that combined application of organic manure and fertilizers significantly increased the straw yield of wheat.

Table 3. Effect of integrated use of manures and fertilizers on the grain and straw yields of wheat

\begin{tabular}{|l|c|c|c|c|}
\hline Treatments & $\begin{array}{c}\text { Grain yield } \\
\left(\mathrm{kg} \mathrm{ha}^{-1}\right)\end{array}$ & $\begin{array}{c}\text { \%yield increase } \\
\text { over control }\end{array}$ & $\begin{array}{c}\text { Straw yield } \\
\left(\mathrm{kg} \mathrm{ha}^{-1}\right)\end{array}$ & $\begin{array}{c}\text { \%yield increase } \\
\text { over control }\end{array}$ \\
\hline $\mathrm{T}_{0}$ (control) & $2291 \mathrm{~b}$ & - & $2972 \mathrm{~d}$ & - \\
\hline $\mathrm{T}_{1}[\mathrm{STB}-\mathrm{CF}(\mathrm{HYG})]$ & $4222 \mathrm{a}$ & 84.29 & $4840 \mathrm{bc}$ & 62.85 \\
\hline $\mathrm{T}_{2}[\mathrm{CD}+$ STB-CF $(\mathrm{HYG})]$ & $4125 \mathrm{a}$ & 80.05 & $5140 \mathrm{ab}$ & 72.95 \\
\hline $\mathrm{T}_{3}[\mathrm{PM}+\mathrm{STB}-\mathrm{CF}(\mathrm{HYG})]$ & $4362 \mathrm{a}$ & 90.40 & $5492 \mathrm{a}$ & 84.79 \\
\hline $\mathrm{T}_{4}[\mathrm{COM}+$ STB-CF $(\mathrm{HYG})]$ & $4092 \mathrm{a}$ & 78.61 & $4953 \mathrm{abc}$ & 66.66 \\
\hline $\mathrm{T}_{5}[\mathrm{FP}($ Farmers' practice)] & $3995 \mathrm{a}$ & 74.38 & $4375 \mathrm{c}$ & 47.22 \\
\hline $\mathrm{SE}( \pm)$ & 315.50 & - & 363.57 & - \\
\hline $\mathrm{CV}(\%)$ & 6.41 & - & 6.70 & - \\
\hline
\end{tabular}

Figure (s) in a column having common letters does not differ significantly.

STB $=$ Soil Test Basis, $\mathrm{CF}=$ Chemical fertilizer, $\mathrm{OM}=$ Organic manure, $\mathrm{CD}=$ Cowdung, $\mathrm{PM}=$ Poultry manure, $\mathrm{COM}$ = Compost, $\mathrm{FP}=$ Farmers' practice, $\mathrm{HYG}=$ High yield goal, $\mathrm{CV}=$ Coefficient of variation, $\mathrm{SE}=\mathrm{Standard}$ error of means

\section{Nutrient uptake by wheat}

The results presented in Table 4 show that the application of cowdung, compost and poultry manure and chemical fertilizers exerted significant influence on the total $\mathrm{N}$ uptake by wheat. The maximum $\mathrm{N}$ uptake of $108.1 \mathrm{~kg} \mathrm{ha}^{-1}$ by wheat was observed in $\mathrm{T}_{1}$. The minimum $\mathrm{N}$ uptake of $56.04 \mathrm{~kg} \mathrm{ha}^{-1}$ was observed in the control. The $\mathrm{P}$ uptake was also significantly influenced by the different treatments (Table 4). The highest $P$ uptake by wheat $\left(16.68 \mathrm{~kg} \mathrm{ha}^{-1}\right)$ was found in $T_{3}$ with the application of poultry manure and chemical fertilizers. The lowest $P$ uptake by wheat of $6.593 \mathrm{~kg} \mathrm{ha}^{-1}$ was found in $T_{0}$. Poultry manure exerted pronounced effect in increasing the $\mathrm{P}$ uptake by wheat compared to cowdung and compost. There was a significant variation in $\mathrm{K}$ uptake by wheat due to the various treatments (Table 4). The highest $\mathrm{K}$ uptake of $90.44 \mathrm{~kg} \mathrm{ha}^{-1}$ by wheat was obtained in the treatment $\mathrm{T}_{3}$ with the application of poultry manure and chemical fertilizers. The lowest K uptake of $44.91 \mathrm{~kg} \mathrm{ha}^{-1}$ by wheat was recorded in the control $\left(T_{0}\right)$. The $S$ uptake by wheat was also affected significantly by different treatments (Table 4). The maximum $S$ uptake $\left(12.02 \mathrm{~kg} \mathrm{ha}^{-1}\right)$ by wheat grain was observed in the treatment $T_{3}$ with the application of poultry manure and fertilizers which was statistically similar with $T_{1}$ [STB-CF (HYG)]. The lowest S uptake of $4.637 \mathrm{~kg} \mathrm{ha}^{-1}$ was noted in the control $\left(\mathrm{T}_{0}\right)$. These results are in agreement with the findings of Khan (2007) and Bodruzzaman et al. (2010) who demonstrated that the nutrient uptake by wheat was influenced significantly by integrated use of manures and fertilizers. 
Table 4. The nutrient uptake by wheat as influenced by integrated use of manures and fertilizers

\begin{tabular}{|l|c|c|c|c|}
\hline Treatments & $\begin{array}{c}\text { N uptake } \\
\left(\mathrm{kg} \mathrm{ha}^{-1)}\right.\end{array}$ & $\begin{array}{c}\mathrm{P} \text { uptake } \\
\left(\mathrm{kg} \mathrm{ha}^{-1}\right)\end{array}$ & $\begin{array}{c}\text { K uptake } \\
\left(\mathrm{kg} \mathrm{ha}^{-1}\right)\end{array}$ & $\begin{array}{c}\text { S uptake } \\
\left(\mathrm{kg} \mathrm{ha}^{-1}\right)\end{array}$ \\
\hline $\mathrm{T}_{0}$ (control) & $56.04 \mathrm{~d}$ & $6.593 \mathrm{c}$ & $44.91 \mathrm{~d}$ & $4.637 \mathrm{~d}$ \\
\hline $\mathrm{T}_{1}[\mathrm{STB}-\mathrm{CF}(\mathrm{HYG})]$ & $108.1 \mathrm{a}$ & $13.91 \mathrm{~b}$ & $81.95 \mathrm{ab}$ & $11.38 \mathrm{ab}$ \\
\hline $\mathrm{T}_{2}[\mathrm{CD}+$ STB-CF $(\mathrm{HYG})]$ & $106.5 \mathrm{ab}$ & $13.17 \mathrm{~b}$ & $75.62 \mathrm{bc}$ & $11.05 \mathrm{abc}$ \\
\hline $\mathrm{T}_{3}[\mathrm{PM}+$ STB-CF (HYG)] & $101.5 \mathrm{abc}$ & $16.68 \mathrm{a}$ & $90.4 \mathrm{a}$ & $12.02 \mathrm{a}$ \\
\hline $\mathrm{T}_{4}[\mathrm{COM}+$ STB-CF (HYG)] & $94.59 \mathrm{bc}$ & $14.80 \mathrm{ab}$ & $65.15 \mathrm{c}$ & $10.55 \mathrm{bc}$ \\
\hline $\mathrm{T}_{5}[\mathrm{FP}$ (Farmers' practice)] & $94.10 \mathrm{c}$ & $13.22 \mathrm{~b}$ & $64.54 \mathrm{c}$ & $10.00 \mathrm{c}$ \\
\hline $\mathrm{SE}( \pm)$ & 7.86 & 1.40 & 6.51 & 1.10 \\
\hline $\mathrm{CV}(\%)$ & 6.88 & 10.05 & 8.77 & 6.37 \\
\hline
\end{tabular}

Figure (s) in a column having common letters does not differ significantly.

STB=Soil Test Basis, $\mathrm{CF}=$ Chemical fertilizer, $\mathrm{OM}=$ Organic manure, $\mathrm{CD}=$ Cowdung, $\mathrm{PM}=$ Poultry manure, $\mathrm{COM}=$ Compost, FP=Farmers' practice, $\mathrm{HYG}=$ High yield goal, $\mathrm{CV}(\%)=$ Coefficient of variation, $\mathrm{SE}( \pm)=$ Standard error of means

\section{Conclusion}

Integrated use of manures and fertilizers improve the soil health and fertility status that in turns improve crop yields. The overall results indicate that the yield of wheat varied considerably among the treatments $T_{1}, T_{2}, T_{3}$, and $T_{4}$ although they received the same amount of nutrients but the sources of nutrients were different. Poultry manure in combination with chemical fertilizers $\left(T_{3}\right)$ produced the highest grain and straw yield of wheat and it took superior position in all other parameters studied including yield components, NPKS uptake. Therefore, it can be concluded that poultry manure in combination with chemical fertilizers can be used successfully in an integrated way for the successful cultivation of wheat.

\section{Acknowledgements}

This research work was supported by Bangladesh Agricultural University Research System (BAURES) Project (No. 2011/41/BAU).

\section{References}

Akhtar, M., Asif, N., Javed, A., Bokhari, S.A. and Wajid, I. 2011. Improvement in nutrient uptake and yield of wheat by combined use of urea and compost. Soil Env. Sci. 30(1): 45-49.

Asit, M. Ashok, K. Dhyan, S. Anand, S. and Ebhin, M. R. 2007. Effect of longterm application of manure and fertilizer on biological and biochemical activities in soil during crop development stages. Bioresource Technol. 98(18): 3585-3592.

Bair, C.A. 2000. Methods of Soil Analysis. Part I and II. Amer. Soc. Agron. Inc. Pub. Madison, Wisconsin, USA.

BARC (Bangladesh Agricultural Research Council). 2012. Fertilizer Recommendation GUIDE-2012 Soils Pub. No. 45 Bangladesh Agricultural Research Council, Farmgate, Dhaka.

BBS (Bangladesh Bureau of Statistics). 2010. Statistical Year Book of Bangladesh. Ministry of Planning, Govt. Peoples' Republic of Bangladesh.

Bodruzzaman, M., Meisner, C.A., Sadat, M.A., and Hossain, M. 2010. Long-term effects of applied organic manures and inorganic fertilizers on yield and soil fertility in a wheat-rice cropping pattern. Wheat Research Centre (WRC), Bangaldesh Agricultural Research Institute (BARI), Nasipur, Dinajpur, Bangladesh, $19^{\text {th }} 142$, August, 2010.

Gomez, K.A. and Gomez, A.A. 1984. Statistical Procedures for Agricultural Research. John Wilely and Sons. New York.

Haque, M.Q., Rahman, M.H., Fokrul, I., Jan, R. and Kadir, M.M. 2001. Integrated nutrient management in relation of soil fertility and yield sustainability under Wheat-Mung-T. aman cropping pattern. On Line J. Biol. Sci. 1(8): 731-734. 
Khan, M.U., Qasim, M. and Khan, I.U. 2007. Effect of integrated nutrient management on crop yields in rice-wheat cropping system. Sarhad J. of Agril. 23 (4): 1019-1025.

Nambiar, K.K.M. 2000. Long-term fertility effects on wheat productivity. Proc. Wheat for non-traditional warm areas, (Saunders. O.A. ed), CIMMYT. I. pp. 516-521.

Page, A.L., Miller, R.H., Keeney, D.R. 1982. Methods of Soil Analysis, Part 2: Chemical and Microbiological Properties. $2^{\text {nd }}$ ed. SSSA, Madison, Wisconsin.

Satyanarayana, V., Prasead, P.V.V., Murthy, V.R.K. and Bodty, K.J. 2002. Influence of integrated use of inorganic fertilizers on yield components of irrigated low land rice. J. 87(1-3): 90-93.

Singh, D., Singh, S.P. and Singh, D. 2002. Response of late sown wheat to seed rate and nitrogen. Progressive Agric. 2 (1): 72.

Toor, P.S., Antil, R.S., Bgarat, S. and Kuhad, M.S. 2009. Effect of different levels of nitrogen and glue waste on wheat. Ann. Biol. 16(2): 147-151.

Yaqub, M., Mahmood, T., Akhtar, M., Iqbal, M.M. and Ali, S. 2010. Induction of mungbean [Vigna radiata (L.) Wilczek] as a grain legume in the annual rice-wheat double cropping system. Pakistan J. Botany. 42(5): 3125-3135. 